\title{
Brontaal- of ontvangtaalagensie in Oranjerivierafrikaans en die ontstaan van Afrikaans ${ }^{1}$
}

\author{
Hans du Plessis \\ ATKV-skryfskool \\ Potchefstroomse Universiteit vir $\mathrm{CHO}$ \\ POTCHEFSTROOM
}

\begin{abstract}
In this article the Orange River variety of modern Afrikaans is investigated in terms of Van Coetsems types of language interference: borrowing and imposition. It is argued that the initial contact between Durch and Khoi resulted in the imposition of Khoi forns on seventeenth-century Durch. These wo forms of interference can still be traced in modern Orange River Afrikaans. A modern variety of a language can thus be studied in order to shed some light on the history of that language.
\end{abstract}

\section{Inleiding}

Die studie van variasieverskynsels in 'n moderne Afrikaanse variëteit oortuig die ondersoeker duidelik daarvan dat die bestaan van linguistiese variasie teruggevoer kan word na sekere historiese werklikhede in Afrikaans. Kortom: die ontstaan van Afrikaans vind duidelik neerslag in die dialektiese aard van moderne Afrikaans.

Heelwat resente variasiestudies in Afrikaans kan gesien word as 'n prikkel vir diachroniese studie. In hierdie verband kan daar ook na die omgekeerde stelling van Louw (1976:53) verwys word. Hy sê naamlik: "Dit blyk dus dat die vraag

I Hicrdic artikel is ' $n$ verwerking van ' $n$ referaat wat oorspronklik aangebicd is by dic kongres oor "Afrikaans in cen veranderende context"- Amsterdam, Nederland (Jan. 1994). 
na die herkoms en ontwikkeling van Afrikaans 'n groot prikkel was vir die dialekstudie ...". Die feit bly dat daar 'n duidelike verband bestaan tussen die geskiedenis van 'n taal en die variasie binne 'n taal. Afrikaans se kontakverloop is in sekere mate dan ook uit sy verskeidenheid af te lei.

In hierdie artikel word daar verwys na ontstaansbeskouinge oor Afrikaans, en daar word dan vanuit 'n effens ander hoek daaroor bespiegel. In die lig van die teorie, soos veral uiteengesit deur Van Rensburg (1989), dat daar vandag drie variëteite van Afrikaans onderskei kan word, naamlik Oranjerivierafrikaans, Kaapse Afrikaans en Transvaalse Afrikaans, word daar in hierdie artikel gepoog om aan te toon dat die ontstaansgeskiedenis van Afrikaans neerslag vind in moderne variasieverskynsels binne ten minste een van die drie variëteite.

Hiermee word Afrikaans nie uniek as kontaktaal gesien nie, in die woorde van Markey (1982:170): alle tale is kontaktale. Die analise word bloot binne die raamwerk van die kontaklinguistiek geplaas. Dit lei daartoe dat daar verder binne die teoretiese raamwerk van Van Coetsem (1988) se twee oordragtipes, naamlik ontlening en imposisie, van die hipotese uitgegaan word dat dialektiese verskeidenheid in moderne Afrikaans teruggevoer kan word na die kontak wat daar veral tussen Nederlands en nie-Germaanse tale bestaan het sedert 1652. Kortom: moderne variasie in Afrikaans is 'n lewende getuienis van die kontakevolusie van Afrikaans.

Daar word in die analise swaar gesteun op die werk van Van Coetsem en van Markey wat die teoretiese raamwerk betref, maar dit wat Louw (1976:4) indertyd al oor die werk van Changion opmerk, naamlik dat die feit dat Changion nie Afrikaanssprekend is nie en daarom nie altyd tussen 'n standaard- of ' $n$ ander vorm kan onderskei nie, ook waar is van sowel Van Coetsem as Markey. Verder gebruik albei die navorsers in hulle analise van Afrikaans deurgaans die ouer bronne. Die feit dat nóg Van Coetsem nóg Markey enige van die moderne literatuur oor Afrikaans raadpleeg, veroorsaak dat hulle uitsprake nie altyd op moderne Afrikaans van toepassing is nie.

Dit is nogal opvallend hoe die eerste taalkundiges Afrikaans feitlik sonder uitsondering as variasieloos sien. Changion self, Mansvelt, Viljoen, en ook S.J. du Toit is gesteld daarop dat Afrikaans van die Kaap tot by die Limpopo een taal is, sonder noemenswaardige verskeidenheid. Die hoofrede hiervoor lê myns insiens daarin dat dit teen die einde van die vorige eeu om Afrikaans as kultuurtaal begin gaan het, en dat dit vir baie van hulle gesentreer het in Afrikaans as nasionale taal. Dit was belangrik vir hulle om Afrikaans van sy patois-etiket te bevry, want toe het dialek nog min of meer onaanvaarbare afwyking beteken. Eintlik is dit eers hier teen 1910 wat T.H. le Roux die verskeidenheid begin raaksien, en dit word dan duidelik deur G.R. von Wielligh bevestig met die verskyning van Ons 
geselstaal in 1925. Dit is eers later, vergelyk byvoorbeeld Scholtz (1980:110111), dat Afrikaans se verskeidenheid aanvaar is. In hierdie artikel word daar aanvaar dat daar mherente variasie in elke taal is.

Verder is dit belangrik dat daar meestal met Afrikaans net die standaardtaal bedoel is. Van Rensburg (1989:440) word in hierdie verband dus gesteun in sy uitspraak, naamlik: "Talle ondersoekers van Afrikaans het in gebreke gebly om te kan onderskei tussen Afrikaans, wat 'n versamelnaam vir die Afrikaanse variëteite is, en die onderskeie variëteite, waarvan Standaard-Afrikaans een is." Ook is daar teen die einde van die vorige eeu met variasie spesifiek geografiese variasie bedoel en nie sosiolinguistiese variasie nie.

Die taalkundige wat hom of haar met die variasie van Afrikaans en met die ontstaansgeskiedenis van Afrikaans besig wil hou, moet natuurlik ook die politieke beletsels op die studie van Afrikaans in die verlede in berekening bring, want die ontstaansbeskrywing en dialekbeskrywing van Afrikaans is aanvanklik gekleur deur die kolonialistiese bril, en later in die meeste gevalle deur die apartheidsbril.

'n Mens sou hierdie onderwerp ook kon benader vanuit die moderne beskouinge oor die aard van kreoolse tale; dan sou hierdie onderwerp deel wees van die debat oor Afrikaans as kreoolse taal. Daar sou seker teen hierdie agtergrond ook sinvolle analise en diskussie kon plaasvind, maar die kreoolsheid van Afrikaans is nie die spesifieke onderwerp van hierdie studie nie, al sou die resultate hiervan net so in die kreoolsgesprek ingevoer kon word. Ons volg hier min of meer Den Besten (1978:5) se vroeëre beskouing, naamlik dat hy hom eenvoudig uit die kreoolsdebat wil uithou.

Dit gaan in hierdie artikel vir my om die analise van Afrikaanse verskeidenheid as brontaalagensie of as ontvangtaalagensie in Van Coetsem se terminologie teen die agtergrond van die kontakgeskiedenis van Afrikaans.

Dit impliseer myns insiens in die eerste plek 'n afdeling oor die ontstaan van Afrikaans en dan 'n beskrywing van hedendaagse variasie en uiteindelik die bymekaarbring van hierdie twee.

\section{Die ontstaan van Afrikaans}

Heelwat is al oor die herkoms van Afrikaans geskryf; teorieë oor die ontstaan van die taal is al so oud as wat die kolonisering van 1652 is. Verskillende teorieë maak Afrikaans as taal ook nie ewe oud nie, want 'n taal se geboortedag word ook bepaal deur die invalshoek en die teoretiese uitgangspunte van die ondersoeker. 
Wat die presiese ontstaansjaar van Afrikaans is, is nie belangrik nie: en 'n mens kan saam met Van Coetsem (1988:134) aanvaar: "1750 is generally cited as the date by which Afrikaans had acquired an identity of its own." Scholtz (1980:109) wys daarop dat ons met sekerheid kan aanvaar dat "die grammatikale struktuur van die alledaagse omgangstaal van die burgers al rondom 1770 in hoofsaak was soos dié van Afrikaans".

Wat egter nie duidelik genoeg in die literatuur gesê word nie, is die feit dat die geskiedenis van Afrikaans in twee duidelike fases uiteenval: Afrikaans voor 1800 en Afrikaans na 1800. Die Suid-Afrikaanse prentjie word duidelik verander, polities, sosiaal en linguisties deur die tweede Britse besetting van die Kaap in 1806. Dit is ook juis teen 1800 dat Afrikaanssprekende groepe soos die sogenaamde Oorlamsgroepe die onmiddellike omgewing van Kaapstad verlaat en al verder weg van die Britse invloed trek.

Markey (1982:169) se driedeling van die ontstaansteorieë van Afrikaans word ook in breë trekke deur Van Coetsem (1988:129) onderskryf, en dit word aanvaar as uitgangspunt vir hierdie bespreking.

Markey wys daarop dat daar wesenlik drie teorieë oor die ontstaan van Afrikaans bestaan:

* Taalverandering as gevolg van vreemde invloed (byvoorbeeld van Platduits, Frans of Koi). Hierdie invloed dan op die 17de-eeuse Nederlands wat algemeen deur die Nederlandse amptenary en seelui aan die vroeë Kaap gebruik is. In hierdie geval is daar taalkontakinvloed, maar nie kreolisering nie.

* Verandering as gevolg van die kreools-vriendelike situasie aan die Kaap wat ontstaan tussen die Nederlandssprekende wittes en hulle vreemdsprekende slawe, ' $n$ gedeeltelike soort kreolisering.

* Verandering toe te skryf aan spontane, ononderbroke en natuurlike ontwikkeling van spesifiek Noord-Hollandse dialektiese kenmerke en inherente rigtings in die grammatiese struktuur van Nederlands.

Hoe ' $n$ mens die diachroniese kwessies ook al bekyk, een van die feite van moderne Afrikaans kan in berekening gebring word: die dialektiese verspreiding van Afrikaans. Dit is eenvoudig moontlik om selfs nou nog geografiese tendense in die variasie van Afrikaans aan te toon wat iets van die ontwikkelingsgeskiedenis van Afrikaans moet verklap. Om Van Rensburg (1989:436) in hierdie verband aan te haal: 
Die onderlinge verbande tussen die afsonderlike Afrikaanse variëteite kan aangedui word deur die Afrikaanse spraakgebied op grond van historiese oorwegings te verdeel in groepe sprekers wat tans nog op groot hoogte geografies identifiseerbaar is, en variëteite van Afrikaans praat wat die volgende oorsprong het:

1. Variëteite deur Nederlanders na Suid-Afrika gebring.

2. Variëteite wat ontstaan uit nie-Nederlandssprekendes se pogings om Nederlands te praat.

Nou kan 'n mens hierdie variëteite suiwer linguisties benader, soos wat dit byvoorbeeld al deur navorsers soos Scholtz, Van Rensburg, Raidt of Ponelis gedoen is, naamlik om uit teksanalises die struktuurgeskiedenis van 'n sekere taalkundige verskynsel te volg, en dan daaruit afleidings oor die ontstaangeskiedenis te maak.

In hierdie artikel word daar egter nie op dié soort diachroniese analise ingegaan nie. Nie omdat so ' $n$ analise niksseggend is nie. Inteendeel, die diachroniese studie is onontkenbaar waardevol. Daar is egter enkele beperkings op die analise van die ou tekste. In die eerste plek is dit logies dat teksanalise op die skryftaal konsentreer. Dit lei tot wat Ponelis (1987:87) uit die mond van Geerts se beeld opmerk, naamlik dat 'n mens bloot die papiergordyn wegtrek om iets van die streektaal te probeer sien. My argumentasie gaan verder aan juis daarom dat die oorgrote meerderheid gebruikers van Afrikaans vóór die twintigste eeu ongeletterd was en daarom word daar min van die werklike spreektaal in die vroeë tekste terug gevind.

Sou 'n mens verder kyk na Raidt (1985:257) se kommentaar op die bekende Mentzel-aanhaling, dan is dit duidelik dat dit hier gaan om die taal van verskillende groepe 'boere'. Selfs ' $n$ analise soos dié van Waher (1988) van die ooreenkoms tussen die Afrikaanse ontkenning en dié van Afro-Portugese dialekte van eilande van die Golf van Guinee, se databasis is geskrewe vorme.

Dit is daarom uiters moeilik om vorme van gesproke Afrikaans van 'n vroeër tyd as empiriese basis te hê. Daar is hier natuurlik die moontlikheid om 'n chronolektiese vorm van taal (vergelyk byvoorbeeld die analise van Van der MerweAfrikaans van Du Plessis, 1993) as gesproke vorm op te teken.

Dit is nie maklik om die sosiale samestelling van die vroeë Kaap te ontrafel nie, maar dit is belangrik om te onthou dat Nederlands sedert 1652 in kontak kom met Koi en 'n bietjie later ook met die taal (of tale) van die slawe. Vyf jaar nadat Van Riebeeck aan die Kaap geland het, was daar 134 Europeërs aan die Kaap: 100 Kompanjieamptenare, 10 vryburgers, ses getroude vroue, 12 kinders en ses gevangenes. 
Die Koi het reeds teen daardie tyd in aanraking met die koloniste gekom. Taalkontak vind daarom reg van die begin af tussen Koi en Nederlands plaas.

In $1658 \mathrm{kom}$ die eerste 170 slawe uit Angola in die Kaap aan. Terselfdertyd kom 228 uit Guinee aan. Later word die Europese bevolking aangevul deur Franse in 1688 en Duitsers, Skandinawiërs en Belge. Teen 1679 was daar maar 287 amptenare, 87 vryburgers, 55 vrouens, 117 kinders, 30 blanke knegte en 191 slawe.

Dit is belangrik om ook te onthou dat die Koi reeds vinnig na die volksplanting as stamme disintegreer. Veral as gevolg van die toekenning van grond aan die vryburgers, stort die totale Koi-stamverbande inmekaar, hoofsaaklik omdat die Koi as nomadiese veeherders ontneem word van hulle hoofekonomiese middel, naamlik vrye beweging tussen weivelde. Verder word die Koi in 1713 en 1755 deur pokke-epidemies ook verminder. Die verval van die Koi het 'n grootskaalse verarming en ook akkulturasie tot gevolg. Vergelyk in hierdie verband Du Plessis (1993) en Nienaber (1989).

Sosiale stratifikasies sluit teen so ongeveer 1750 (net ruweg gemarkeer) die volgende in: slaaf, as onvrye op die onderste vlak; die Hottentot, as vrye maar ekonomies verslaaf, net bokant die slaaf; die Oorlam, ' $n$ ontstamde stand, met sterk besef van eiewaarde en ekonomies soms vooraanstaande, kultureel vooruitstrewend, baie van hulle gekerstend, baie in besit van wa en wapens; en ten slotte, die sogenoemde Baster wat soms ook Europese bloed het en veelal dieselfde vlak as die Blanke wil en soms ook kan handhaaf. (Nienaber, 1989:24-25.)

Teen die tyd dat Afrikaans as taal beslag kry, met ander woorde teen die einde van die agtiende eeu, kan daar vir Afrikaans drie duidelike variëteitstrome aangetoon word, naamlik Kaapse Afrikaans, Oranjerivierafrikaans en Oosgrensafrikaans. Dit is nie die doel van hierdie artikel om die driedeling in besonderhede te motiveer nie, want dit word duidelik gedoen in verskeie ander bronne, byvoorbeeld in Van Rensburg (1984 en 1989) en ook in L.T. du Plessis (1986)

Dié driedeling is in elk geval ook nie nuut nie, en C.J. van Rijn het so 'n indeling reeds aan die begin van hierdie eeu gemaak (vergelyk H. du Plessis, 1986b:38 e.v.). As ' $n$ mens die evolusie van die sosiale gemeenskap aan die Kaap in gedagte hou, kan die linguistiese driedeling in verband gebring word met ' $n$ gemeenskapsdriedeling: Kaapse Afrikaans word hoofsaaklik teen 1800 gebruik deur die gemeenskap wat 'n groot element van vroeëre slawe insluit, Oranjerivierafrikaans sluit die taal van die Koi, Oorlam en die Bastergroepe in, wat daarop neerkom dat daar ' $n$ beduidende Koi-element moet wees, terwyl Oosgrensafrikaans die taal van die Hollandse boere as hoofelement het. 
Teen 1800 is die beweging van Oosgrensafrikaanssprekendes weg van Kaapstad af in 'n oostelike rigting ver gevorder en die wegbeweeg van Oranjerivierafrikaanssprekendes noordwaarts, al met die Kaapse weskus op is ook aan die gang.

Die Oosgrensers trek later in die negentiende eeu, veral met die Groot Trek van die dertigerjare, die Suid-Afrikaanse binneland van Natal, die Vrystaat en Transvaal binne. So versprei Oosgrensafrikaans na die binnelandse gebiede wat teen die einde van die negentiende en in die loop van die twintigste eeu die ekonomiese en politieke kern word. So ontwikkel hierdie vorm van Afrikaans tot Standaardafrikaans.

Die sprekers van Kaapse Afrikaans bly in hoë mate in die Weskaap agter, en die mense wat Oranjerivierafrikaans gebruik, trek al verder noord sodat ook die grootste dele van die suide van Namibië teen die middel van die negentiende eeu Afrikaans is.

Daar is vroeër reeds daarop gewys dat daar in die geskiedenis van Afrikaans onderskei moet word tussen die periode voor 1800 en dié daarna. Dit is myns insiens 'n belangrike onderskeid, want sedert 1806 is veral die Afrikaanssprekende van die suidelike dele van die Kaap blootgestel aan Engels as dominante taal. Eers later (veral in die tweede helfte van die vorige eeu) word die taalkontak tussen Engels en Oosgrensafrikaans ook nouer. Dit is ook belangrik dat die variëteit wat standaardtaal word juis na 1900 , in die tyd dat hierdie vorm van Afrikaans as kultuurtaal ontwikkel word, in noue kontak, selfs onder druk van Engels kom. Hierteenoor bly Oranjerivierafrikaans relatief vry van die imperialistiese invloed van Engels.

Dit is egter die posisie van Afrikaans voor 1800 wat ons verder in hierdie artikel interesseer. Daar word vervolgens aandag geskenk aan die taalkontaksituasie voor die invloed van Engels op Afrikaans. Die invloed van Engels is in die literatuur al relatief goed beskryf, byvoorbeeld Donaldson (1988). Die taalkontak sal binne die raamwerk van Van Coetsem se oordragtipes onder die loep geneem word.

\section{Ontlening en imposisie}

Van Coetsem (1988) onderskei tussen ontlening en imposisie. Hy argumenteer dat 'n term soos interferensie nie presies genoeg is om daarmee die fynere onderskeide te tref wat by taaloordrag in die geval van taalkontak nodig is nie. Dit gaan in sy onderskeid in wese om 'n presisering van terme. Ontlening (borrowing) en imposisie (imposition) is dan twee spesifieke soorte oordrag waarin die agent van 
die leenhandeling belangrik is. Oordrag is dus nie bloot 'n kwessie van die oorneem van materiaal uit die een kontaktaal na 'n ander nie. Dit is juis wie hierdie oorname doen, wat die aard daarvan bepaal. Vir Van Coetsem word die spreker dus die punt waarvandaan hy wil definieer. Vir die spreker wat 'n bepaalde taal leer, wat in aktiewe kontak met 'n taal kom, is daar ' $n$ brontaal en 'n ontvangtaal ter sprake. As die ontvangtaalspreker die agent van die oordrag is, dan is die oordrag van materiaal van die brontaal na die ontvangtaal in so 'n geval ontlening. Hoewel Van Coetsem (1988:3) Engels en Frans as voorbeelde gebruik, kan ons in die lig van ons argumentasie Afrikaans gebruik om die beginsel van ontlening te verduidelik: As 'n Afrikaanssprekende 'n Engelse woord gebruik as hy Afrikaans praat, is die oordrag van materiaal ontlening, byvoorbeeld:

\section{Ek like hierdie nuwe skoene.}

As die oordragagent egter nie die ontvangtaal as moedertaal het nie, sal die spreker materiaal uit die brontaal, wat dan sy moedertaal is, op die ontvangtaal afdwing, byvoorbeeld as ' $n$ Engelssprekende Afrikaans praat, sal die Engelse uitspraakpatroon op die Afrikaans afgedwing word:

\section{Ek kontak jou vanoggend.}

Dit is so dat sekere domeine van ' $n$ taal stabieler is as ander domeine. Dit word byvoorbeeld redelik algemeen in die variasietaalkunde aanvaar dat variasie nie op al die analisevlakke van dieselfde omvang is nie. Omdat dit so is, sal die oordragagent ' $n$ rol speel in die aard van die materiaal wat oorgedra word. As die ontvangtaalspreker die agent is (dus in die geval van ontlening), sal die ontvangtaal se stabiele domeine (byvoorbeeld die fonologiese of die sintaktiese) bewaar word. Die Afrikaanse moedertaalspreker sal waar Engels die brontaal is, dan maklik op die woordeskatvlak leen, maar nie so maklik op die sintaktiese vlak nie. In die geval van imposisie, waar die agent die brontaal as moedertaal het, sal die agent makliker van sy stabiele domeine op die ontvangtaal afdwing. So sal die Engelssprekende wat Afrikaans gebruik makliker sintaktiese materiaal op die ontvangtaal (Afrikaans in hierdie geval) afdwing. Die brontaalagent bewaar met ander woorde die stabiele domeine van sy taal.

Van Coetsem (1988:3) som self sy siening so op: die oordrag van materiaal van 'n brontaal na 'n ontvangtaal raak die minder stabiele domeine van die brontaal, in die besonder die woordeskat, in die geval van ontlening, en die oordrag van materiaal van die brontaal na die ontvangtaal by imposisie raak die meer stabiele domeine, byvoorbeeld die fonologie

Wanneer Van Coetsem Afrikaans as gevallestudie betrek, voer hy egter nie sy teorie tot sy volle konsekwensie nie. As 'n mens na Afrikaans voor $1800 \mathrm{kyk}$ 
teen die agtergrond van Van Coetsem se twee oordragtipes, dan sou dit so moet wees dat Oosgrensafrikaans (latere Standaardafrikaans) meer voorbeelde van ontlening behoort te vertoon as Kaapse en Oranjerivierafrikaans, want die oordragagent in die geval van Oosgrensafrikaans was die Afrikaansprekende. Hierteenoor was die oordragagent in die ander twee gevalle onderskeidelik die veeltalige slawe en die Koisprekers.

Bestudeer 'n mens die analises van Afrikaanse taalhistorici, is dit duidelik dat daar in Standaardafrikaans sprake is van ontlening, terwyl daar in die geval van Kaapse Afrikaans en van Oranjerivierafrikaans duideliker tekens van imposisie is.

Dit is hier weer belangrik om tussen Afrikaans voor en na 1800 te onderskei, want na 1800 is die Kaapse en Oranjerivierspreker 'n Afrikaanssprekendes wat Afrikaans as ontvangtaal gebruik in die kontak met Engels. Veral die woordeskat van hedendaagse Weskaapse Afrikaans onderskryf hierdie hipotese.

Deur die moderne variëteite van Afrikaans te ondersoek binne die raamwerk van Van Coetsem se oordragtipes, kan daar lig gewerp word op aspekte van die ontstaansgeskiedenis van Afrikaans in die tydperke voor en na 1800.

Ek wil in die volgende afdeling dan uitgaan van die hipotese dat die drie variëteite van Afrikaans vandag onderskei sal kan word vir sover Transvaalse (of dan Oosgrensafrikaans) meer ontlening vertoon en dat die ander twee, Kaapse en Oranjerivierafrikaans, meer imposisie sal hê, omdat taaloordrag in die geval van Transvaals ontvangtaalagensie het en die ander twee meer brontaalagensie.

\section{Verskeidenheid in moderne Afrikaans}

S.A. Louw (1976) gee 'n betreklik volledige oorsig oor die Afrikaanse dialekstudie tot die sewentigerjare van hierdie eeu. Dit is duidelik dat variasiebelangstelling in die vorige eeu hoofsaaklik 'n belangstelling was na die mate waarin Nederlands afwyk van Afrikaans. Dit blyk byvoorbeeld duidelik uit die woordelyste in Mansvelt se Proeve van een Kaapsch-Hollandsch Idioticon van 1884. Dit is eintlik eers met Von Wielligh (wat in elk geval geen taalkundige was nie) wat met die verskyning van Ons geselstaal in 1925 die belangstelling in dialektiese verskeidenheid bimne Afrikaans prikkel. T.H. le Roux doen streng gesproke die eerste werklike variasieanalise in sy Leidense proefskrif van 1910. Later kry ons ook die waardevolle bydrae van Abel Coetzee in die veertiger- en vyftigerjare. Maar die volle krediet kom eintlik Louw self toe, want afgesien van Rademeyer se Kleurling-Afrikaans (1938) en dié van Abel Coetzee (1951), is die reusetaak wat Louw met die opstel van die Afrikaanse Taalatlas onderneem, die enigste wetenskaplik gefundeerde taalgeografie. 
Die belangstelling in die Afrikaanse taalverskeidenheid bly oor die algemeen egter, tot selfs in die sewentigerjare, hoofsaaklik 'n belangstelling in taalgeografie.

Met die publikasie van Claassen en Van Rensburg se Taalverskeidenheid (1983) kry die belangstelling in die verskeidenheid in Afrikaans nuwe momentum. Die verskyning van Van Rensburg (1984) se omvattende verslag oor die Afrikaans van die Griekwas en Du Plessis (1986a) se verslag oor die Afrikaans van Namibië, gee ook nuwe stukrag aan die sosiolinguistiese beskrywing van variasie in Afrikaans. Verskeie verhandelings en proefskrifte oor variasie sien in die loop van die tagtigerjare die lig.

Die beskrywing van die verskeidenheid in hedendaagse Afrikaans bevestig die driedeling in Kaapse Afrikaans, Oranjerivierafrikaans en Transvaalse Afrikaans. Natuurlik moet die subvariasie binne hierdie drieledige variasie erken word, maar daar is redelike eenstemmigheid onder Afrikaanse taalkundiges oor die driedeling.

Hierdie artikel is nie 'n poging om die struktuurverskille van die drie uiteen te sit nie. Daar bestaan heelwat uiteensettings van die struktuur daarvan. Verder aan wil ek bloot probeer aantoon dat modeme Afrikaans ' $n$ verskeidenheid vertoon wat, as dit in terme van Van Coetsem se oordragtipes geplaas word, juis ondersteunend kan wees vir ' $n$ historiese en eietydse driedeling.

In die verdere bespreking word hoofsaaklik op Oranjerivierafrikaans gekonsentreer.

Daarmee word daar hoegenaamd nie bedoel dat die ander twee variëteite nie ook binne die Van Coetsem-raamwerk beskryf kan word nie. Ek meen dat daar juis veel te sê is oor die oordragtipes in Kaapse en Transvaalse Afrikaans. Kaapse Afrikaans moet anders hanteer word, want die aanvanklike slawegemeenskap is ' $n$ veeltalige gemeenskap, wat nogtans as brontaalagente funksioneer in die eerste jare van kontak met Nederlands. Later kom hierdie sprekers weer in kontak met Engels - dan egter as ontvangtaalagente. Dit is ook goed moontlik dat selfs die oorname van latere Arabiese woorde (vergelyk Davids, 1990) ontlening is, en nie imposisie nie. Hierdie oorname vind blykbaar plaas soos met Engelse oordrag, eers in die negentiende eeu, nadat Afrikaans reeds as moedertaal onder die slaweafstammelinge gevestig is. Teen die middel van die negentiende eeu was Afrikaans onder hulle byvoorbeeld reeds gevestig as onderrigmedium, ook in die godsdienstige skole van die Moslems (Davids, 1990:19). Daar is in die verskillende kontaktydperke dus sprake van eers imposisie en dan na 1800 ontlening.

Dit is verder ook belangrik om in gedagte te hou dat daar op een enkele variëteit van Afrikaans gekonsentreer word, naamlik Afrikaans soos wat dit gepraat word 
in die Noordweste van Kaapland, tot so ver oos as Vryburg en dan ook in die suidelike dele van Botswana, byvoorbeeld by Werda en in die omgewing van Mamuno, en verder in die hele suidelike Namibië tot by Windhoek, en in Khorixas deur die Riemvasmakers. Hierdie variëteit staan vandag algemeen as Oranjerivierafrikaans bekend.

Daar word rekening gehou met analises van verskynsels soos die dubbele ontkenning, reduplikasie, die betreklike konstruksie en selfs die vir-konstruksie, soos wat hierdie analises deur byvoorbeeld Scholtz of Raidt of G.S. Nienaber in verskeie publikasies gedoen word. Die artikel ignoreer ook nie die jonger analises soos dié van Den Besten (1978 en 1987) nie, maar al hierdie analises is analises van verskynsels wat net so in Standaardafrikaans gebruik word. Die analises is dus eenvoudig nie net van toepassing op een variëteit van Afrikaans nie.

Oosgrensafrikaans, ook dan bekend as Transvaalse Afrikaans, en ook die huidige Standaardafrikaans vertoon voor 1800 ontvangtaalagensie, maar gedurende hierdie tydperk is Nederlands as ontvangtaal ook die dominante taal in die taalkontaksituasie, terwyl Engels na 1800 die dominante taal is - daar vind in die loop van die negentiende en die begin van die twintigste eeu grootskaalse taalverplasing ten gunste van Engels plaas. Dit is hierdie Oosgrens-variëteit van Afrikaans wat vir Afrikanemasionalisme opgeëis word en wat teen die draai van die eeu tot heel laat in die twintigste eeu hemude vemederlandsing ondergaan.

Oranjerivierafrikaans is die vorn van Afrikaans wat heel van die begin van die kolonisering in 1652 af al moes begin beslag kry, want met die landing van Van Riebeeck is Nederlands en Koi in onmiddellike kontak. Die Nederlanders leer nie Koi nie, want "die Hottentotse taal was vir Europeërs berug moeilik" (Scholtz, 1980:37), en die Koi word gedwing om Nederlands as ontvangtaal te gebruik. In hulle pogings om Nederlands te praat, tree die Koi-sprekers dus reg van die begin af op as brontaalagente. Daarom sal daar in hierdie vorm van Nederlands (en so ook nog reste daarvan in modeme Oranjerivierafrikaans) sprake moet wees van imposisie, wat inhou dat die Nederlands van hierdie sprekers materiaal uit Koi as brontaal op hom afgedwing kry uit die meer stabiele domeine, byvoorbeeld die sintaksis, morfologie of fonologie. Domein word deur Van Coetsem (1988:3) gebruik as ekwivalent vir die term analisevlak in die Variasietaalkunde, en binne die Variasietaalkunde word die sintaksis-domein ook as stabiel beskou: Hudson (1982:46) wys daarop dat die sintaksis die meeste weerstand teen variasie bied. Dit is dus so dat Oranjerivierafrikaans variasie op al die domeine moet vertoon as ' $n$ mens dit as ' $n$ variëteit wil beskou waarin imposie meer as ontlening voorkom. As Oranjerivierafrikaans imposisie het, moet die brontaalagensie daarvan aangetoon kan word, wat variasie op al die analisevlakke impliseer. Die onstabiele domeine, byvoorbeeld die woordeskat en 
selfs die klankvlak sal nie ter sprake kom nie, omdat dit min oor imposisie sê. Daar word daarom verder aan op die morfologiese en sintaktiese domeine van Oranjerivierafrikaans gekonsentreer, en ook net op verskynsels wat variasie ten opsigte van Standaardafrikaans vertoon

Gebaseer op verskeie analises en op bandmateriaal van moderne Griekwasprekers, Rehoboth-sprekers en sprekers van Oranjerivierafrikaans uit die omgewing van Mamuno in Botswana, Mier en Rietfontein in die Noordweste van Kaapland, en in die suide van Namibië is variasie op al die analisevlakke in dié variëteit duidelik sigbaar.

Die tipiese morfologiese variasie van hedendaagse Oranjerivierafrikaans lê byvoorbeeld in die dubbele meervoudsuitgange byvoorbeeld kinderse, klipperse, goeterse, vrouense, veëns. Verder kry 'n mens ook die reduplikasie van die verkleiningsuitgang: biesietjıe, sakkıetjie, huisietjie. Die verdubbeling van 'n suffiks is ook by die vorming van die vergrotende trap van die byvoeglike naamwoord opvallend: beterder, meerder. Die besitskonstruksie met se is ook algemeen in hierdie variëteit van Afrikaans, byvoorbeeld hy se kos, ons se werk. En dan ten slotte ook die veelvoorkomende goed-konstruksie sodat selfs 'n eienaam die goed-aanvoeging duld: Ek was al oralster, Meneer, tot daar in Japan-goed!

Wat die sintaktiese domein betref, kom daar ook beduidende variasie voor, byvoorbeeld by die opheffing van die onderskeid tussen manlik en vroulik by die persoonlike voornaamwoord: Toe hardloop my ma daar van die hys af, toe sê hy

Seker die duidelikste sintaktiese kenmerk van Oranjerivierafrikaans is in die gebruik van die medewerkwoord, veral dan die oorgebruik van dit wat tradisioneel die verbale hendiadis genoem word: Julle staan en speel. In moderne Oranjerivierafrikaans word die onderskeid tussen die sogenaamde direkte en indirekte skakelwerkwoord egter algemeen opgehef: Julle staan speel. Hieruit kom dan voorbeelde soos: Nou kan hulle raaisels sit gesels. Miskien kan hy mos hier rond lê vorstaan.

"Die struktuur van die infinitief in GA is seker een van die heel duidelikste gemerkte voorbeelde van sintaktiese variasie ..." (Du Plessis, 1984:159). Dit gaan hier om die sintaktiese bondeling van om en $t e$, soos in: Daardie entjie is 'n harde sakietjie om te daar wegkom. Meneer. Soms word die te ook verdubbel: Nou het ons hom nou gevra om te ok vir ons te help om te die plek te kry.

Hiermee word daar nie voorgegee dat dit 'n struktuuranalise op morfologiese en sintaktiese vlak van Oranjerivier is nie, en die verskynsels word ook in die voorgaande bespreking nie verklaar nie. Dit sou byvoorbeeld moontlik wees om hier- 
die variasiepatrone terng te voer na Koi, soos wat 'n mens sou kon aantoon dat die Standaardafrikaanse woord hoeka (Ek was hoeka al lus om in Amsterdam te kom), terug gevoer kan word na die woord huka (lankal) wat vandag nog in moderne Nama gebruik word (vergelyk die Nama/Damara spelreëls van 1977, p. 14).

Wat uit die bespreking hopelik duidelik is, is die feit dat variasie in Oranjerivierafrikaans juis in die stabiele domeine voorkom, wat dui op imposisie eerder as op ontlening wat op sy beurt daarop dui dat Oranjerivierafrikaans ontstaan as gevolg van brontaalagensie, en dat Nederlands aanvanklik die ontvangtaal was vir die Koi-sprekende oordragagent wat uit die brontaal (waarskynlik dan Koi) patrone op sewentiende-eeuse Nederlands afdwing.

\section{Slot}

Deur te fokus op 'n bepaalde moderne Afrikaanse variëteit, en deur die identifisering van die oordragtipe wat in die variasie ter sprake is, sou ' $n$ mens dus kon vasstel wat die agent vir die oordrag van materiaal is. Die vasstelling van brontaal- of ontvangtaalagensie kan help om nuwe lig te werp op die kontakgeskiedenis van Afrikaans. So sou die analise van dialektiese verskynsels in moderne Afrikaans ook iets te sê hê vir die ontstaansgeskiedenis van Afrikaans.

\section{Bronnelys}

Claassen, G. \& Van Rensburg M.C.J.. reds. 1983. Taalverskeidenheid. Kaapstad : Academica.

Coetzee, A. 1951. Taalgeografiese studies I. Johannesburg : Universiteit van die Witwatersrand.

Davids, A. 1990. Words the Cape Slaves Made: a Socio-Historical-Linguistic Study. S.A. Tydskrif vir Taalkunde, 8(1): 1-24, Februarie.

Den Besten, H, 1978. Cases of Possible Syntactic Interference in the Development of Afrikaans. In: Muysken, P. (red.) Amsterdam Creole Studies II. Amsterdam : Publikaties van het Instituut voor Algemene Taalwetenschap. Nummer 20. p. 5-57.

Den Besten, H. 1987. Die niederländische Pidgins der alten Kapkolonie. In: Boretzky. N., Enninger, W. \& Stolz T. reds. Beiträge zum 3. Fssener Kolloquium ïber Sprachwandel und seine bestimmenden Faktoren. Bochum : Studienverlag Dr. N. Brockmeyer.

Donaldson, B. 1988. The Influence of English on Afrikaans: A Case Study of Language Change in a language Contact Simation. Pretoria : Serva.

Du Plessis. H. 1984. Sintaktiese variasie in die Afrikaans van Griekwas. In: Van Rensburg, M.C.J. Die Afrikaans van Griekwas in die tagtigerjare. Ongepubliseerde RGN-verslag. Pretoria.

Du Plessis. H. red. 1986a. Aspekte van Swidwesafrikaans met spesiale verwysing na die Afrikaans van die Van der Merw'es. Ongepubliseerde RGN-verslag. Pretoria.

Du Plessis. H. 1986b. 'n Afrikaanse chronolek? S.A. Tydskrıf vir Taalkunde, 4(4): 15-49

Du Plessis. H. 1993. Variasieraalkunde. (Derde druk.) Pretoria : HAUM-Literêr

Du Plessis, L.T 1986. Afrikaans in beweging. Bloemfontein : Patmos. 
Hudson, R.H. 1982. Sociolinguistics. Cambridge : Cambridge University Press.

Louw, S.A. 1976. Taalgeografie en die studie van Afrikaans. In: Studies oor die Afrikaanse taal. Uitgegee vir die Suid-Afrikaanse Akademie vir Wetenskap en Kuns. Johannesburg : Perskor-uitgewery. p. 53-63.

Markey, D. 1982. Afrikaans: Creole or Non-creole. Zeitschrıfi für Dialektologie und Linguistik, IL. Jahrgang, Heft 2.

Nama/Damara-spelreëls no 2. 1977. Departement van Bantoe-onderwys, SWA. Windhoek John Meinert.

Nienaber, G.S. 1989. Khoekhoense stamname. Kaapstad : Academica.

Ponelis, F.A. 1987. Uit die geskiedenis van die Afrikaanse betreklike konstruksie. S.A. Tydskrıf vir Taalkunde, Geleentheidsuitgawe, nr. 5.

Rademeyer, J.H. 1938. Kleurling-Afrikaans. Amsterdam : N.V. Swets \& Zeitlinger.

Raidt, E. 1985. Vrouetaal en taalverandering. Tydskrff vir Geesieswetenskappe, 24(4):256286.

Scholtz, J. du P. 1980. Wording en ontwikkeling van Afrikaans. Kaapstad : Tafelberg.

Van Coetsem, F. 1988. Loan Phonology and the Two Transfer Types in Language Contact. Dordrecht : Foris Publications.

Van Rensburg, M.C.J. 1984. Die Afrikaans van Griekwas in die tagtigerjare. Ongepubliseerde RGN-verslag. Pretoria.

Van Rensburg, M.C.J. 1989. Soorte Afrikaans: In: Botha, T.J.R. (hoofred.) Inleiding tot die Afrikaanse taalkunde. Kaapstad : Academica. p. 436-467

Von Wielligh, G.R. 1925. Ons geselstaal. Pretoria : J.L. van Schaik

Waher, H. 1988. Eenders of anders? 'n Vergelyking tussen die ontkenning in Afrikaans en Afro-Portugees. S.A. Tydskrif vir Taalkunde, 6(1):109-128. 